\title{
Student-Athlete School Selection: A Family Systems Theory Approach
}

\author{
Claire C. Schaeperkoetter, Jordan R. Bass, \\ and Brian S. Gordon \\ University of Kansas
}

\begin{abstract}
The primary focus of this study was to examine the role family members play in the college selection process for NCAA Division III student-athletes. The role of family members in the college selection process has been studied for nonathletes, NCAA Division I athletes, NCAA Division II athletes, and at a cross-divisional level for specific NCAA sports. In such research related to intercollegiate student-athletes, research has primarily been conducted quantitatively with the use of survey techniques. Little research exists specifically exploring the role of family members in the college selection process for NCAA Division III athletes. Based on the lack of research, the overarching Division III philosophy, the pure participation rates of NCAA Division III athletes (more than 180,000 current Division III athletes), and the ideal fit of Family Systems Theory to this selection process, this research study is fitting. In this project, sixty-nine student-athletes participated in semistructured interviews at eleven different NCAA Division III institutions. Five prompts directly related to potential family influence were asked. Data were analyzed using open coding based on a priori and emergent themes. Responses are collectively summarized and representative responses are presented verbatim. Results are also discussed through the framework of Family Systems Theory and related back to previous literature on the role of the family in the college selection process.
\end{abstract}

Keywords: college choice, family influence, recruitment, Division III, family systems theory

Family members play an instrumental role in introducing their children to sport (Baxter-Jones \& Maffulli, 2003). Further, family involvement in children's decisions related to sport continues with the college selection process of prospective NCAA student-athletes (DeWaele \& Lounsbery, 2007; Maher, 2007; Ryan, Groves, $\&$ Schneider, 2007). For these reasons, Family Systems Theory-a theoretical approach that accounts for the social interactions in a family system (related to sport socialization) as well as how external entities can affect the family structure (related to the college decision-making process) — can serve as a guide for those 
involved in the college-decision making process of prospective NCAA studentathletes. Specifically, Family Systems Theory takes into account the role members both within and external to the family can have on behavioral decisions made by one or more family members (Dore 2008; Collins, 2012). Thus, exploring the college decision-making process of prospective NCAA student-athletes through the lens of Family Systems Theory can provide insightful guidance to those within the family structure (prospective student-athletes and their parents) and those external to the family (coaches and athletic administrators).

The very nature of the college selection process inherently factors in psychological, sociological, economic, geographical, and academic factors (Kinzie, Palmer, Hayck, Hossler, Jacob, \& Cummings, 2004). Due to its interdisciplinary approach between sociology, psychology, and home economics (Broderick, 1993), the fundamentals of Family Systems Theory can be applicable to the college selection process as well. The tenants of Family Systems Theory indicate that each family member functions as an important component of the integral system (Dore, 2008; Collins, 2012). Family Systems Theory is founded on the concepts that the family is interdependent and is uniquely semiporous and responsive to external factors in the environment (Collins, 2012). In addition, the theory aligns with the college selection process because the family unit (namely parents and prospective college students) has to rely on each other and on external information about colleges to make an appropriate college choice. Thus, the purpose of this study is to explore the application of Family Systems Theory to prospective NCAA Division III student-athletes.

The authors argue the niche of the college selection process of NCAA Division III student-athletes is particularly relevant for two primary reasons. First, the very philosophy of Division III athletics is that the student-athletes prioritize academics and are fully integrated into the university setting. For these reasons, one could argue then that these prospective college students would approach the college decisionmaking process in the same manner as a student without an interest in participating in athletics in the college setting. As will be discussed later, family members have been found to play a vital role in the general college decision-making process. However, competing as a student-athlete in Division III athletics is a very serious and time-consuming endeavor. Thus, there is reason to believe that prospective Division III athletes could align themselves with prospective NCAA Division I and Division II athletes by prioritizing athletics in the college decision-making process. These contradicting rationales for the priorities of prospective Division III studentathletes - that they should prioritize academic and institutional fit or they should prioritize athletic fit-demonstrates that prospective Division III student-athletes may form their own norms for the college decision-making process.

\section{Literature Review}

In the following pages, the theoretical underpinnings of the current study are detailed. First, a brief description of the NCAA Division III structure and previous research conducted in the realm of Family Systems Theory are detailed. To provide further context, earlier work surrounding sport socialization and the college selection process of both athletes and nonathletes is presented. In all, the aim of this review is to highlight past work on the role of the family system in decision-making, both 
in and out of sport. The authors end the review with a discussion of prior research specifically examining the college decision-making process for student-athletes.

\section{NCAA Division III}

The NCAA Division III level has both more student-athletes and institutional members than Division I or Division II ("About NCAA Division," 2014). With more than 180,000 Division III student-athletes at more than 450 institutions, Division III purports to differentiate itself from other NCAA Divisions by having student-athletes that are fully integrated into the academic and cocurricular experience of the institution at-large ("About NCAA Division," 2014). The idea is that by not offering athletic scholarships, the student-athletes will play for the "love of the game" and will place the highest priority on their own academic endeavors. The Division III Philosophy Statement illustrates these sentiments by asserting,

Colleges and universities in Division III place the highest priority on the overall quality of the educational experience and on the successful completion of all students' academic programs. They seek to establish and maintain an environment in which a student-athlete's athletics activities are conducted as an integral part of the student-athlete's educational experience ("Division III philosophy," 2014, para. 1)

In a publication aimed at discussing the Division III Platform to an audience of student-athletes and parents, it is stated Division III athletics aims to allow students to, "access financial aid for college without the obligations of an athletics scholarship" and to, "continue to compete in a highly competitive athletics program and retain the full spectrum of college life" ("Division III strategic," 2009, p. 1). Thus, Division III differentiates itself primarily by the fact that student-athletes do not receive financial aid based on athletic skill. Based on this distinction, Division III student-athletes will be more integrated into the general student body and will place the highest priority on academic success. However, while Division III studentathletes are not necessarily as skilled athletically as their Division I and Division II counterparts, they are just as driven to succeed athletically (Herzberger, 2014).

\section{Family Systems Theory}

Family Systems Theory began to develop in the 1960s and 1970s (Broderick, 1993) out of General Systems Theory as a need arose to develop a theory more specifically applicable to the family system (Dore, 2008; Collins, 2012). In its most fundamental sense, Family Systems Theory is a theoretical approach for understanding family dynamics, roles, familial structures, patterns of communication, boundaries within family members, and boundaries between the family and outside entities (Rothbaum, Rosen, Ujiie, \& Uchida, 2002). Initially developed more intentionally for family therapy, Family Systems Theory, "has emerged as a major paradigm for family analysis among other, non-clinical disciplines such as sociology, psychology, home economics, social work, and human communications" (Broderick, 1993, p. 4). It is also seen as the prevailing contemporary paradigm for understanding and explaining the psychosocial dynamic between people in the modern-day world (Dore, 2008). Collins (2012) asserts, "families are considered systems because they 
are made up of interrelated elements or objectives, they exhibit coherent behaviors, they have regular interactions, and they are interdependent on one another" (p. 54). The family is in and of itself a social system (Broderick, 1993). According to Ferrari et al. (1998), a family system has, "the richness of their interconnections, as well as the fullness of how their relationships define who they are and how they will behave both within and outside the family system" (p. 365).

A thorough discussion of the main tenets of Family Systems Theory warrants breaking down the theory into its primary elements: nonsummativity, interrelational connections, circular causality, communication, family rules and boundaries, and homeostasis (Ferrari, Verbanac, \& Cane, 1998). A closer look at these primary tenets of Family Systems Theory will lay the foundation for exploring the college selection process of NCAA Division III student-athletes through the lens of Family Systems Theory. Nonsummativity is defined by the idea that the sum of family behavior is greater than the sum of its parts. That is, overall family behavior is more complex than simply adding up the individual behaviors and characteristics of each family member (Ferrari et al., 1998). Inherent in this idea of nonsummativity is the notion that family members are interdependent and rely on each others' characteristics and skill set to make up the familial system as a whole (Collins, 2012). In line with this idea, Ferrari et al. (1998) also emphasizes interrelational connections as a postulate of Family Systems Theory. Family members are linked by long-lasting emotional and relational ties as opposed to short-term or contextual similarities.

Circular causality is the idea that every action within a family system has a reaction in some form. Behavior is often patterned but rarely completely linear in nature (Ferrari et al., 1998). Members interact in patterns based on rules (e.g., the parents determine the chore list of each child). Most, if not all, rules are unwritten. The cyclical patterns of behavior and rule management provide the parameters for behaviors of individual members and the family system as a whole (Collins, 2012). Although this circular causality makes it such that interactions within the family are not linear in nature, each interaction-whether verbal or nonverbal-communicates interpersonal messages. Ferrari et al. (1998) posits, "Family Systems Theory suggests that every communication has at least two functions: 1) to transmit information or content and 2) to define the nature of the relationship between the individuals" (p. 366).

Each family system has boundaries (as governed by rules and interaction patterns between family members). These rules help to organize the interactions between family members, establish the boundaries between the family system and the external environment, and provide stability to the family system (Collins, 2012; Ferrari et al., 1998). Importantly related to the idea that rules establish boundaries, the family system functions on a continuum between an open and closed boundary system. That is, each system includes or excludes various amounts of influence that come from outside the family system. While no family system is purely an open system or purely a closed system, families that fall closer toward the open system on the continuum tend to behave based on external influences; closed family systems are more isolated and self-contained (Collins, 2012). Thus, the family system is semiporous in nature. That is, the family behaves in a way indicating it is aware of external influences but it maintains a semblance of behaving according to rules and behaviors previously regulated within the family unit. Finally, Family Systems Theory indicates that behavior of each family member and of the family as 
a whole is influenced by a need for a homeostatic environment. Restated, families are inclined to maintain stability; doing so can often mean resisting change. With an established understanding of the elements of Family Systems Theory, it is pertinent to first discuss the relevance of the Division III context and research on the college selection process. Then, by employing the specific methodology used in this study, we will be able to discuss the results of the examination by linking together Family Systems Theory, Division III athletics, and the college selection process.

\section{Role of the Family Dynamic in Sport Socialization}

To explore the role of family in the college decision-making process for Division III athletes through the lens of Family Systems Theory, it is first important to understand the role parents may have played in the athletic lives of their children up until the point of making the college decision. In their book titled Who's Game Is It Anyway?, Baltzell, Ginsburg, and Durant (2006) provided an age-by-age breakdown of how parents can be best supportive of their child's athletic endeavors. Their discussion provides a good baseline with which to understand how the sport socialization process could occur and the dynamic role parents have in this process. Tips are categorized based on the age of the child and include "The Early Years" (Ages 0-6), "The Elementary School Years" (Ages 6-12), "The Teen Years" (Ages 13-18) and "The College Years" (19 and Beyond). In their section on "The Early Years", the authors addressed the sport socialization process by encouraging parents to introduce sports as an enjoyable physical activity. They also advised parents to have their children rely on other siblings to spark interest in sport (Baltzell et al., 2006). During the "Elementary School Years", the authors encouraged parents to focus on praising their children when the children demonstrate discipline, persistence, and teamwork. The primary advice for parents with teens is to realize that the child himself or herself has to genuinely love the sport to have the drive to dedicate increased time honing his or her skills; the parent cannot make his or her child love a sport. The authors also touted the importance of acknowledging that for many teenage athletes, quitting is not necessarily a copout and parents understand that for most teenagers, pursuing playing a sport in college is not necessarily realistic (Baltzell et al., 2006).

Research conducted by Wuerth, Lee, and Alfermann (2004), Wheeler (2012), and Sage (1980) all add credence to the notion that parents play a large role in the sport socialization process of their children. Wuerth, Lee, and Alfermann (2004) distributed the Parental Involvement in Sport Questionnaire (PISQ) to 193 young athletes and their parents. Results indicated that the athletes perceive high levels of praise and understanding. They also found slight differences in how mothers and fathers perceive their role in the sport socialization process. Mothers perceive their role as one of support and understanding whereas fathers view their role as one in which they need to give more directive instructions to their children. In their discussion surrounding these results, Wuerth et al. (2004) mentioned that when parents invest there is an appropriate medium or support for parents to have with their children. They suggested, "Whereas moderate involvement seems to facilitate a sport career, both underinvolved, disinterested parents and, at the opposite extreme, overly engaged parents, may play a disruptive role" (p. 22). Finally, while discussing 
that there are four phases of athletic career development (initiation, development, mastery, postcareer), parents typically are most involved in the initiation phase (Wuerth et al., 2004).

Through performing semistructured interviews with eight "sporty" children and their parents in North Wales, Wheeler (2012) gleaned responses indicating that the family unit served as primary facilitator of the sport socialization process. Serving as a bridge of sorts between research on the sport socialization process and the role of parents in the college decision-making process for prospective student-athletes, Sage (1980) studied the potential gender differences in the sport socialization process of current intercollegiate athletes. Results indicated that parents tended to have at least some background in sport participation and that parents of male athletes tended to be more involved in the sport socialization process than the mother counterparts (Sage, 1980). Along with the above-mentioned sport socialization examinations, family has also been shown to play a major role in the college decision-making process, both for nonathletes and athletes.

\section{College Decision-Making Process for Non-Athletes}

To date, an abundance of literature exists on the college selection process of students that do not participate in collegiate athletics (Kim \& Rury, 2007; Heller, 2013; Perna \& Kurban, 2013; Smith, Pender, \& Howell, 2012). Research on trends in higher education point to the idea that parents are more involved in their college student's lives (Levine \& Dean, 2012). In a study of trends in the college decision-making process over the past 50 years, Kinzie et al. (2004) argued that several important factors have remained the same: parents continue to play an influential role in the decision-making process, cost of attendance is important, and proximity to parents is a contributing factor. Furthermore, the junior year of high school is frequently the year in which students decide where to apply (Kinzie et al., 2004).

By performing a comprehensive follow-up study to the 1947 President's Commission on Higher Education that forecasted a changing landscape in higher education based on the post-World War II era, Kim \& Rury (2007) examined whether these forecasted changes in enrollment patterns had indeed taken place in the United States. More students were graduating from high school, more females enrolled in colleges and universities, and college enrollment increased across the board (Kim \& Rury, 2007). Heller (2013) highlighted that there continues to be a greater stratification in higher education based on family income levels. As family income increases, the likelihood of entering a four-year institution increases while the likelihood of entering a community college decreases. Furthermore, since the early 1980s, the average cost of tuition for a 4-year private institution has increased from approximately $\$ 10,000$ per year to $\$ 28,500$ for the 2011-2012 academic year, an increase of $181 \%$. In the same time period, annual tuition costs for a 4-year public increased $268 \%$ from approximately $\$ 2,000$ to approximately $\$ 8,200$. At the community college level, tuition costs increased from $\$ 1,070$ per annum to \$2,963 (Heller, 2013). Perna and Kurban (2013) assert that college enrollment rates continue to vary based on race, family income, and other demographic variables. Knowledge and comfort with the college enrollment process is related to the parents' occupation and own educational background. Perna and Kurban (2013) also 
critique the conception that looking at the role of the family in the college selection process assumes traditional, normative parental involvement in which the student comes from a White, middle-class household.

\section{Student-Athlete Decision-Making Process}

There has also been a substantial amount of research on the college selection process of Division I student-athletes and the potential role family members play in that process (DeWaele \& Lounsbery, 2007; Maher, 2007; Ryan, et al., 2007). When studying the college decision-making process of 290 student-athletes at the University of Nevada-Las Vegas (UNLV), DeWaele and Lounsberry (2007) found that family perceptions of the institution were found to be a major contributor to the college decision. Jordan and Kobritz (2011) also stressed, "the thoughts, feeling and opinions of parents or legal guardians are generally considered to be primary influences in the university selection process of a student-athlete" (p. 429). In addition, by completing both a meta-analysis of previous work on previous studies of prospective NCAA basketball student-athletes and by using a word association methodology, Ryan et al. (2007) supported previous literature that indicated that parents often play an important role in the college decision-making process for prospective NCAA student-athletes. Similarly, Maher (2007) addressed how the lines of communication (and involvement of parents) in recruiting have changed with the use of text messaging and social media. He proposed stricter regulation of these relatively new forms of communication to protect prospective student-athletes and to keep the recruiting process more insular.

Further, Doyle and Gaeth (1990) distributed "choice sets" to 605 Division I student-athletes to study the school selection process of NCAA Division I studentathletes. Research participants had to choose from different hypothetical university profiles to simulate the college selection process. Results indicated that, above all other factors, student-athletes valued the amount of athletic scholarship they would be receiving more than other factors (Doyle \& Gaeth, 1990). Kankey and Quarterman (2007) researched factors influencing college choice by surveying 196 NCAA Division I softball student-athletes. Responses pointed to five factors that were most influential in the college decision-making process (in no particular order): amount of financial aid, the head coach, availability of desired program/major, postgraduation career opportunities, and fit with team (Kankey \& Quarterman, 2007).

Jordan \& Kobritz (2011) focused specifically on NCAA Division II softball teams and collected data from sixty-nine student-athletes who completed the Strength of University Selection Factors survey. Coaching staff, academic characteristics, softball program, and financial aid were found to be the most important factors contributing to college choice for these Division II softball student-athletes. Finally, Pauline et al. (2004) collected data from 320 baseball student-athletes who completed a 32-item Influential Factors Survey for Student Athletes (IFSSA). They found Division III student-athletes place more emphasis on academics that Division I and Division II student-athletes in the college decision-making process. Continuing a similar line of study, Pauline (2010) surveyed 792 male and female college lacrosse student-athletes. These student-athletes also completed the IFSSA. Results 
indicated that lacrosse student-athletes from Division II and Division III institutions valued academics more highly that their Division I counterparts. Ultimately, while research exists on the role of the family in the college decision-making process of nonathletes, and family has been included as an ancillary variable in examinations of athletes, in-depth, explicit analyses on the role of the family in the college selection process specifically for prospective NCAA Division III student-athletes do not exist. This study aims to explore the application of Family Systems Theory to the college decision-making process of prospective Division III student-athletes. The very nature of Division III athletics and the tenets of Family Systems Theory provide reason to believe that Family Systems Theory could serve as an explanatory tool for how the family unit is specifically involved in deciding where a prospective Division III student-athlete will attend college.

\section{Method}

Semistructured interviews were conducted with sixty-nine student-athletes at eleven different NCAA Division III institutions. Authors One or Two conducted all interviews in person on the home campus of the student-athletes after initially contacting athletic directors and coaches to request access to the university. The four types of Division III institutions (academically elite, large public, mission driven private, liberal arts institution) were represented (Bass, Pfleegor, Katz, \& Schaeperkoetter, 2014) in the sample to ensure both that a holistic understanding of the role of the family in the college decision-making process at the Division III level could take place and that any potential differences across typologies would be discovered. Institutions were initially solicited to obtain a representative sample of the four types of institutions. Once this goal was reached, convenience sampling was used based on the willingness of university administrators to allow access to their campus and student-athletes. In all, Authors One and Two interviewed student-athletes on campuses in Arkansas, Colorado, Illinois, Iowa, Missouri, New York, North Carolina, and Wisconsin. A range of two to thirteen student-athletes were interviewed at each school based on schedule and availability. Interviews were concluded once saturation was achieved. Gratton and Jones (2004) described data saturation as the stage, "where any further data collection will not provide any different information from that you already have, that is you are not learning anything new" (p. 153).

\section{Procedures}

An interview guide (Johnson \& Christensen, 2008) was used and a semistructured approach was undertaken where, "the researcher adopts a flexible approach to data collection, and can alter the sequence of questions or probe for more information with subsidiary questions" (Gratton \& Jones, 2004, p. 141). Each interview was conducted on the respondent's campus (typically in a conference room in the athletic department) and lasted between 15-30 minutes and included questions related to 
recruiting, student-athlete experience, family influence, perceptions of Division III athletics, and time commitment. Prompts directly related to family influences were:

What role did your family play in the decision making process? (Family members are interdependent, nonsummative, interrelational)

Have others in your family played college sport? (Family members interact in patterns, circular causality)

If you made an on-campus visit, did anyone in your family join you on the visit? (Family systems have semi-porous boundaries, contradicts homeostatic endeavors)

Was the visit a big influencer of your decision? (Family systems have semiporous boundaries, contradicts homeostatic endeavors)

How much did the cost attending play into your decision? (Family members behave according to rules, communication)

A diverse array of gender ( 37 female, 32 male), graduating class, and sport participation was present in the sample. Of the sixty-nine participants, 25 were seniors in regards to athletic eligibility, 22 were juniors, 12 sophomores, 9 freshmen, and one graduate student. Sixteen played varsity basketball, nine played soccer, seven baseball, seven tennis, six track and field, five softball, five swimming and diving, four football, four volleyball, two lacrosse, two golf, one hockey, and one gymnastics.

\section{Researcher Positionality}

As Misener and Doherty (2009) stated, "researcher positionality acknowledges the impact of the researchers' background, assumptions and relationships with... subject matter to provide more thoughtful and critical representation of ourselves within our research" (p. 466). Both Authors One (women's basketball) and Two (men's tennis) were Division III student-athletes at different institutions. As such, the authors acknowledge they find added importance in the examination of this context and have a personal interest in the setting. Further, this familiarity likely allowed the authors to relate to the participants on a deeper level and ask more probing questions. Authors One and Two also used their previous playing experience as an access tool when initially soliciting interview participants. In the initial e-mail to ask for participants, the authors were able to include that they were former Division III athletes to develop a point of connection in hopes of increasing their likelihood of participating in the study.

Authors One or Two also conducted every interview on campus in a face-toface format. The authors believe this led to a richer data set in line with Morgan and Symon's (2004) belief that, "in electronic interviewing the relationship is in many ways 'disembodied' - distanced by time and space - and decontextualized" (p. 28). Further, this method potentially increased the access permitted by administrators; as one athletic director told Author Two, "we get data collection requests 
every day and ignore them but because you were willing to travel to campus we responded to you."

\section{Analysis}

Author One transcribed the responses and clarified any ambiguities with the interview participants. Both deductive (the use of established theory to guide the analysis) and inductive (taking direction from the data) approaches were used to analyze the data and open coding (Corbin \& Strauss, 2008) was performed. Responses were first coded independently by Authors One and Two based on a priori themes from the interview prompts and theoretical framework. Next, Authors One and Two collectively identified new emergent themes that were not present in the past literature. When differences in coding appeared between authors, they were discussed until agreement was reached (Hambrick \& Kang, 2014). To account for reliability and validity, the authors followed the five verification strategies described by Morse, Barrett, Mayan, Olson, and Spiers (2002): methodological coherence, appropriate sample, collecting and analyzing concurrently, thinking theoretically, and theory development. The responses are both collectively summarized and presented in verbatim form below (using student-athlete pseudonyms selected by the researchers) to give voice to the researchers and participants. As Corbin and Strauss (2008) argued, "though we break data apart, and identify concepts to stand for the data, we also have to put it back together again by relating those concepts" (p. 198).

\section{Results}

The results of the open coding process are presented below. Responses to questions directly related to family influences generally fell into one of four theme categories that were also related to Family Systems Theory: (1) family members are interdependent, (2) family members behave according to rules, (3) family members interact in patterns, and (4) family systems have semiporous boundaries. In addition, emergent themes related to the previous playing experience of parents and siblings materialized during the inductive analysis. Further, overlap existed between interdependence and semiporous boundaries based on the inherent external research involved in the college selection process.

\section{Family Members Are Interdependent, Nonsummative, and Interrelational}

In response to questions regarding the general role of the family in the decision making process, student-athletes gave responses that ultimately tied back to one overarching theme: their parents were intimately involved in the process, willing to help narrow down the list of potential schools, and open to discuss their personal opinions. Participant responses did vary on how "hands on" the parents were in the process. However, regardless of how proactive the parents were in the process, all student-athletes indicated their parents made it clear they were available to discuss 
college options and would be supportive of the decision their child made. It was made abundantly clear that the parents were there to be supportive and available to consult throughout the process. Josh, a senior baseball player at a mission-driven private institution, conveyed his parents were quite supportive when he said,

They definitely helped me a lot through the recruiting process, helped me decide where I wanted to go. And ultimately for me, it was about being able to stay somewhat close to home for sure. It was an informal like we'd always have a conversation about it every other day or something like that and I mean, they supported my decision $100 \%$ whether I wanted to go here or any other school. They were always behind me $100 \%$.

Kelsey, a junior on the women's basketball team at a mission-driven private institution echoed this idea of parental support and involvement and the importance of being close to family:

(My family played a) huge role, I'm not a very good decision-maker and they supported me every step of the way. I have a really big family and most of them live in [my hometown, an hour away from this university] so every one of them was there for me at some point in making that decision.

Ultimately, this overarching theme that parents were supportive of their child throughout the college decision-making process illustrates the interdependence of family members, the nonsummative nature of family interactions, and the interrelational dynamics that form some of the components of Family Systems Theory.

\section{Family Members Behave According To Rules and Rely on Communication}

Responses varied as to how hands-on parents were in the college decision-making process. Kim, a senior on the gymnastics team at a large public institution, provided a representative quote for those that indicated her parents took a very proactive, rules-oriented approach in the process:

Process-wise, we kind of looked at - they asked me what states I wanted to live in and I just circled all the states I'd want to live in. And then we looked at what schools had gymnastics in all those states. And then we looked at from there, what academic programs they had because I knew I wanted to do [physical training] or exercise science. Something like that. And we looked at all the programs there and looked at how good their team was to see if it was within range or not. And that's how we started narrowing it down. And then we started visiting schools from there.

Clearly, Kim's parents and her had a very interactive, formulated, and streamlined process to find a good fit both academically and athletically. Furthermore, her response indicated that proximity to her hometown did at least factor somewhat into her decision.

Responses to questions about the weight of cost in the decision provided the clearest evidence that the parents and children behaved according to specific rules 
laid out about the college finances. Participant responses to the question about how much cost attending played into their decision indicated that, again, having open conversations with their parents was very important. Responses varied about how much cost affected their ultimate decision but the general theme remained that specific parameters were laid out about the parental role in financing college expenses. Responses from student-athletes assert this notion that parents were involved in discussions about cost of attending the desired institution and that parents made their stance on cost very clear throughout the college selection process. Thus, some students said their parents told them not to worry about cost. Others laid out specific parameters of what the cost limits would be. However, we argue that the very fact that the parent and students openly discussed whether the student should consider cost does show transparency in the communication.

Danielle, a senior on the women's tennis team at a small liberal arts institution said, "My parents just said if you love tennis, if you want to do it, we're willing to do whatever to make you happy". Her parents were supportive of her decision, whatever it was, and did formally acknowledge their rules about finances in the college selection process. Stacey, a junior on the women's basketball team at an academically elite institution, echoed these sentiments about the open conversations she had with her parents regarding cost of attendance when she said, "My parents have just been such a big proponent of we'll make it work. Because it's important and if that's the school for you, it's worth it... So I mean it was obviously a discussion we had to have, but in the end I think when they realized how perfect this school was for me, they said we'll figure it out."

Again, responses differed in specific content, but the general theme of communicating with parents about the pending decision remained the same. Sarah, a sophomore softball player at a liberal arts college, gave a representative response for the contingent of interviewees that had a more formalized process for cost of attendance. She said, "It (cost) played quite a big role. I would say that was $90 \%$ of what I considered. My parents said they'd give me so much money and then anything after that set amount would be my own debt. So I was definitely - that made me way more aware of cost."

Gabe, a senior on the men's swimming team at an academically elite institution, illustrated that formalized rules about the role of cost of attendance were in place before the college decision was made. Gabe said,

My dad paid his way through college and law school and kind of made it his goal from the time he was 21 - he tells us - was to make sure that he would pay for his sons' college. So the way it worked was before I was even applying for colleges, he sat me and he sat my brother down and said, 'you're going through this application process right now. I will pay for your college as long as you make sure you maintain above a 3.5 and it's kind of a family expectation that when you're older, you're going to pay it forward as well.",

Interviewee responses differed on the actual methods family members used to simplify the college decision-making process. However, responses were very similar in the sense that family members relied on communication with each other throughout the process and that rules for the decision-making process (however varied they may be) were laid out early on in the process. 


\section{Family Members Interact In Patterns and Circular Causality}

Responses indicated two primary ways in which patterned behavior played a role in the college selection process: parents that played sports in college gave opinions about playing sports in college and siblings' experiences affected decisions in the college selection process.

\section{Parents' Playing Experience}

Again, interviewee responses for this category fell into one of two categories: (a) their parent(s) played sports in college and that made them want to play in college or (b) they didn't play in college but they were supportive nonetheless of their child's endeavors to pursue playing a sport in college. Jonathan, a junior on the men's lacrosse team at an academically elite institution fell in line with the former category in that his parents both played in college and their experiences as a student-athlete led him to pursue playing the same sport in college. Jonathan said,

My mom went to (another college) and played lacrosse. My dad went to (another college) and played lacrosse... My parents just, I followed in their footsteps a little bit. So they sort of set a good example of what a good college experience might be for me. So I kind of drew off of that they had done and made a decision from there. They didn't push me into sports or anything like that.

Kate, a junior on the women's basketball team at a large public institution, further exemplifies the role of parents who were former athletes when she said, "my dad was my assistant coach on the varsity team so he was always like communicating with my head coach and always kind of part of that process because he played college basketball as well." While not all interviewees had parents who were former college athletes, those respondents that did have parents who were former college athletes indicated that there were specific discussions about the experiences of being a college student-athlete.

\section{Siblings and College Selection}

Interestingly, respondents pointed to experiences that their siblings had and how those experiences patterned their own processes for selecting a college. Not all interviewees had siblings that had to decide whether to play a sport in college, but the interviewees that did mention the role of their siblings all mentioned how their siblings had a powerful impact on their decision. Mike, a junior on the baseball team at a large public institution, said his brother's Division III experience helped him rule out a particular school. Mike said, "Well I had an older brother who went to [school] and the coach there - I heard some horror stories from him and he ended up quitting because he hated the coach. It wasn't fun. [School] was cut from day one."

Matty, a senior baseball player at a large, public institution similarly pointed to this patterned behavior of learning from sibling experiences when he said, "I grew up idolizing him (my brother) a bit. He was a pretty good basketball player as well in high school and went on to play at [local school]. Not that I wanted to do everything he did, but I gained a great passion for basketball as well." While the 
previous examples pointed to the impact that older siblings had on their decisionmaking process, Casey's response indicated that she knew that her experiences as a collegiate student-athlete were having an impact on her younger siblings. Casey, a sophomore women's lacrosse player at an academically elite institution said, "I have two little sisters. One is a senior in high school. She's going to play lacrosse at (another school) next year. And then my other sister is in $8^{\text {th }}$ grade - she wants to come to (this school) for lacrosse so we'll see."

Both the representative quotes from interviewees who had either parents who were former athletes or siblings who are involved in higher level athletics indicate patterned behaviors in the college selection process between family members. In addition, interviewee responses represented the notion of Family Systems Theory that causality in behavior exists (i.e., the fact that parents participated in college athletics had a direct influence on the college decision-making process for the study participants).

\section{Family Systems Have Semi-Porous Boundaries}

Almost all responses from all of the interviewees alluded to this notion of the family system having semiporous boundaries. This idea is inherently and intimately tied into the whole college selection process because of the very nature of college. The insular family structure changes because college not only becomes the primary external influence on the child, but also because the very make-up of the family structure dramatically shifts once the student matriculates. The entire college selection process-from recruiting, to researching academic and athletic programs, to taking campus visits - illustrate that the family system is welcoming information and influences from outside the family system boundary. Specific responses about the role of the campus visit in the college selection process best illustrate this idea of taking in external information to help the members of the family have requisite information to make the college selection decision.

All students did not directly indicate that family members joined them on the visit, but did indicate that their parents at least knew it was important for the student-athletes to get a clearer picture of the university setting. Matty, a senior on the baseball team at a large public institution, indicated that he had been on several informal campus visits with his parents when they would travel with him to tournaments in high school that were on the college campus. Matty stated, "we played a couple of tournaments here in the summer that my parents would come with and I was just very familiar with the campus. I know wherever I wanted to go my parents would support me."

Another representative response came from Josh, a senior baseball player at a mission-driven private institution. In response to being asked whether his family joined him on the visit, he said, "It was my dad. It was me and my dad when we came for the visit. He was just as impressed as I was whenever I took my visit." One particularly salient response from an interviewee succinctly conveyed the role the visit ultimately had on their college decision. Of her visit, Kelsey, a women's basketball player at an academically elite institution, said, "My parents came with me on my visit. And it was the first time I had every been to (this area)... but I just loved (the area). And my parents told me later that as soon as they saw me here, they were like 'this is gonna be where she's gonna go to school'". 
Ultimately, interviewee respondents indicated the acknowledgment that transitioning from being a high school athlete living at home to becoming an intercollegiate student-athlete would change the logistical nature of the family structure. The nature of the selection-process from the perspective of a prospective student-athlete includes gathering information about both the athletic and academic programs of different colleges and universities. Such a gathering of information indicates the families are respondent to influences from those outside the immediate family, which further indicates that families have semiporous boundaries.

\section{Discussion}

The prompts directly related to family influence all drew responses that indicated significant family involvement in the college decision-making process. In responses to the questions about the role family played in the decision making process, whether others in the family played college sport, parental presence on an on-campus visit, and cost as a decision-making factor, the sixty-nine interviewed student-athletes indicated the presence of an overall theme of parental support, reliance on opinions from parents and the child (interdependence), and involvement in the college selection process. Furthermore, results also showed that discussions with family members occurred about whether cost would serve as a large factor in the decision-making process. Using Family Systems Theory as an explanatory tool for interviewee responses serves two purposes. First, it necessarily helps to compare results to previously discussed research regarding the role of the family in the college selection process. Secondly, it serves as a mechanism with which to explain why responses indicated parental involvement and support in the college decision-making process.

Before a directed discussion of the role of the family in the college decisionmaking process of prospective NCAA Division III student-athletes, it is first important to briefly discuss the relative homogeneity in responses across both different types of institutions and different sports. In short, responses were largely homogenous across different types of institutions, sports, demographic variables (such as race and social class), and number of parents in the household remained relatively static. The large majority of interviewees came from middle-class or upper-middle-class, two parent households. Possibly due to these similarities in family demographic variables, interviewees showed no noticeable differences across sports. These questions intentionally asked about the role of family and family factors in the college selection process. Thus, it is understandable, based on the idea that there were little demographic differences across student-athletes, that responses were relatively similar in nature.

Because there are no athletic scholarships at the Division III level, there is a greater likelihood that these student-athletes come from at least a middle-class household. Specifically, this falls in line with Heller's (2013) research that shows there is stratification in higher education based on family income levels. As family income increases, the likelihood of entering a four-year institution increases. Interviewees indicated cost of attendance either did not play a factor or if it did, they had strategies to make the education affordable. Furthermore, while Perna 
and Kurban (2013) critiqued that exploring the role of the family in the college selection process typically is from the perspective of those students from a White, middle-class background, interviewee data matched the data that Perna and Kurban (2013) critiqued most. Thus, if research on the role of the family in the college decision-making process is indeed based on the assumption that students come from two parent, middle-class backgrounds, the demographic variables from this representative sample of student-athletes aligned with such findings.

The similarity in nature of the demographic variables from interviewees in this study can be explained in part by NCAA student-athlete demographics reported by The Institute for Diversity and Ethics in Sport (Lapchick, Fox, Guia, \& Simpson, 2015). In their annual report on the diversity in NCAA sport, data both about stark demographic differences between sports at the Division I level and also about overall demographic trends at the Division III level substantiate the idea that we found a relatively homeostatic demographic environment in interviewees in this study. In a report on cross-divisional racial differences, by noting the differences simply in African-American participatory rates, Lapchick et al. (2015) indicated that the Division III level could arguably be the most static in terms of diversity. For the 2013-2014 school year, 25\% of Division I male student-athletes were African-American; $10.6 \%$ were African-American at the Division III level. For the 2013-2014 academic year, 15\% of Division I female student-athletes were African-American; 5.5\% were African-American at the Division III level. This report released by the Institute for Diversity and Ethics and Sport provides some possible rationale for why we found few stark differences in responses based on the sport of each interviewed student-athlete.

\section{Family Members Are Interdependent, Nonsummative, and Interrelational}

The idea that results from this study very much mirror the college selection process of students of the general student body (nonathletes) adds credence to the general philosophy of NCAA Division III athletics: Division III student-athletes are fully integrated into the general student body of the institution at-large. Specifically, responses in this study fall in line with previous research by Levine and Dean (2012) and Kinzie et al. (2004) that indicate high parental involvement and support in the lives of college-aged students.

\section{Family Members Behave According To Rules and Rely on Communication}

The communication and behavior patterns about the decision-making process also tied into the Family Systems Theory importance on the rules process. In the college selection process for these prospective NCAA Division III student-athletes, the rules were mostly unwritten. For example, there was never any mention of explicit rules about parents supporting children, parents loving their children, or parents having interest in the future of their kids, but each respondent indicated these rules were naturally incorporated and conveyed throughout the college selection process. Lastly, in regards to rules affecting the behavior of members in the family system, 
rules about the weight of cost of attendance seemed to be more directly conveyed between the parents and the child.

In regards to this research paralleling the idea of the importance of cost of attendance as discussed by Kenzie et al. (2004), cost of attendance was a factor that was discussed between student-athletes and parents. Among all the questions posed to the interviewees about the role family members play in the college decision-making process, responses regarding the role cost of attendance played in the decision-making process varied the most. There was a split between whether student-athletes said cost of attendance was a large deciding factor or whether the student-athletes were told by their parents to make their decision without highly weighting the cost of attendance. However, while responses varied as far as whether cost was a deciding factor, all respondents indicated that there were open discussions with parents about the cost of attending potential colleges. The existence of these open discussions further points to the idea of parental involvement in the college selection process.

\section{Family Members Interact In Patterns and Circular Causality}

Respondents also seemed to pattern their behavior after those in their family they deemed to have previous experience in the college selection process. That is, prospective student-athletes were forthcoming that they patterned their behavior after their older siblings or parents if their siblings or parents had played sports in college. The idea of relying on the experiences of siblings falls in line with the suggestions encouraged by Baltzell et al. (2006).

\section{Family Systems Have Semi-Porous Boundaries}

The authors argue that the most important application of Family Systems Theory to the college selection prospect of prospective NCAA Division III athletes is directly related to two of the fundamental foundations of Family Systems Theory: interdependence of family members and the family system as a semiporous system. It is interesting that the parents and child relied on each other heavily (interdependence) throughout the process but the process itself would actually lead to a fundamental shift in the insular construction and definition of that family system. By having a more porous family system boundary to glean as much valuable information as possible to make the correct college decision, families had to preemptively accept what would happen when the child actually went to college: the boundaries of their family would dramatically shift. The idea of college selection is nearly entirely about external influences (such as recruiting) and making decisions based on the external environment. The parent and child together had to decide in which external environment the child wants to continue his or her athletic, academic, and social life in an physical environment that is different than the insular home of the immediate family.

Lastly, in regards to interviewee responses lining up with the third important factor in the college selection process indicated by Kenzie et al. (2004), proximity to parents/family and/or hometown played a role in the college selection process for some Division III student-athletes. While this question was not directly asked of the interviewees, it is important to point out that some student-athletes voluntarily 
discussed the importance of staying close to home. As examples, Kim indicated that she circled states on a map where she would consider attending school and the geographic location of school played a role in the initial vetting of potential schools. Kelsey indicated that it was important that she stay nearby her close network of family. Danielle indicated she stayed in the same area for college because she was comfortable with the area. Bruce indicated some football programs from out-ofstate institutions recruited him, but he decided early on in the recruiting process he wanted to stay closer to home. Overall, interviewee responses further the notion that Division III student-athletes are representative of the general student body. As such, the important factors in their college decision-making process mirror the important factors in the college decision-making process for prospective college students that are not college-bound athletes.

It is, however, worthwhile to briefly review the primary thematic differences that did emerge from interviewee responses. At the academically elite institutions, like at the other types of institutions, the student-athletes were representative geographically and academically of the general student body. The idea that academically elite student-athletes representatively come from diverse geographic locations could indicate a fundamental difference in the college selection process. Specifically, prospective student-athletes looking at academically elite institutions have to find not only a good fit athletically and academically but also have to deal with the additional factors of the academically elite institution's stringent academic standards and higher cost of attendance. While interviewees from these academically elite institutions still indicated overall parental support and in-depth communication throughout the college selection process, the fact that many Division III studentathletes at academically elite institutions chose to attend college further away from home, on average, than student-athletes from other types of institutions indicates that the family may have played a different role in the college selection-process (i.e., staying close to home was not necessarily a top priority).

\section{Practical Implications}

In addition to this study relating to previous studies on important factors for general students, results for this study also tie in to previous research on the college decision-making process of NCAA athletes. Importantly, results from this research not only point to the positioning of the college decision-making process of prospective NCAA Division III athletes, but also provides practical implications for the field at large. Specifically, these results should hopefully provide beneficial information to three of the primary parties involved in the recruiting process of prospective NCAA Division III student-athletes: players, parents, and coaches.

Information gleaned from this study should provide guidance for how players and parents can approach the college decision-making process. They should continue to rely on the interdependence of the units within the family system, establish formal or informal rules for the recruiting process (i.e., determining if formal guideless for establishing realistic financial options for college), and understand that, because the college decision-making process relies on so many internal and external factors, the recruiting process will not be linear in nature. Different schools will recruit with different levels of vigor at different times. Academic financial aid packages will vary based on each institution and the timeline of such financial 
aid package will differ. By understanding that the recruiting process will affect the family as a system, family members can be better prepared when entering the college-decision making process.

Lastly, as posited earlier, the idea of going to college importantly challenges one of the main ideals of the family system according to Family Systems Theory: families desire to maintain a homeostatic, stable home environment. Being so responsive to the very externally focused recruiting process, families will have to acknowledge that their stable environment will soon change when the prospective student-athlete matriculates to his or her chosen college or university. College coaches can benefit from this information by being sensitive about this aversion to dramatic changes to the functioning of the family system.

\section{Limitations and Future Research}

This research study was not without its limitations. Due to this study specifically looking at the role of the family in the college selection process, it is limited by the fact that the authors only spoke to students and not parents. The authors also only interviewed current student-athletes, thus the authors had to rely on current student-athletes correctly remembering intricate parts of the recruiting process. Some of the interviewed student-athletes were several years removed from the college selection process so there may have been some gaps in their reporting of the college selection process.

Further, there are numerous directions for future research. It would be interesting to continue this qualitative approach with student-athletes to explore the importance of academics in their decision-making process and the typical timeline and practices for recruiting at the Division III level. In addition, it would be meaningful to address some of the aforementioned limitations of this study by interviewing parents of student-athletes and to interview student-athletes and parents that are in the midst of the college selection process. Future research could help to build on the four proposed Division III typologies of large public, mission driven private, liberal arts, and academic elite (Bass et al. 2014). Finally, the qualitative nature of this study provides a baseline with which to use for further research on the college selection process for NCAA student-athletes using the scope of Family Systems Theory. To date, there has been relatively little qualitative research on the college decision-making process for prospective NCAA athletes (Finley \& Fountain, 2008).

\section{Acknowledgments}

Funding for this manuscript was partially provided by the University of Kansas School of Education Research Support Fund and the University of Kansas Doctoral Research Grant.

\section{References}

About NCAA Division III. (2014). Retrieved from http://www.ncaa.org/about?division=d3. Bass, J.R., Pfleegor, A.G., Katz, M., \& Schaeperkoetter, C.C. (2014, April). Why D3? A holistic exploration of Division III institutions and their student-athletes. Paper 
presented at the 7th Annual College Sport Research Institute Conference on College Sport, Columbia, SC.

Baltzell, A., Ginsburg, R. D., \& Durant, S. (2006). Whose game is it, anyway?: A guide to helping your child get the most from sports, organized by age and stage. Houghton Mifflin Harcourt.

Baxter-Jones, A. D., \& Maffulli, N. (2003). Parental influence on sport participation in elite young athletes. The Journal of sports medicine and physical fitness, 43(2), 250-255. PubMed

Broderick, C.B. (1993). Understanding family process: Basics of family systems theory. Sage (Atlanta, Ga.).

Collins, L. (2012). The modern family business: Relationships, succession and transition. Houndmills, Basingstoke, Hampshire: Palgrave Macmillan.doi:10.1057/9781137001337

Corbin, J., \& Strauss, A. (2008). Basics of qualitative research: Techniques and procedures for developing grounded theory (3rd ed.). Thousand Oaks, CA: Sage.

DeWaele, C. S., \& Lounsbery, M. (2007). Student-athlete recruitment at the University of Nevada-Las Vegas. Research Quarterly for Exercise and Sport, 78(1), A-109.

Division III philosophy statement. (2014). Retrieved from http://www.ncaa.org/governance/ division-iii-philosophy-statement.

Division III strategic positioning platform. (2009, December). Retrieved from http://www. ncaa.org/sites/default/files/DIII_Strategic+Platform_DIII_Logo_Dec_09.pdf

Divisional differences and the history of multidivision classification. (2014). Retrieved from http://www.ncca.org

Dore, M.M. (2008). Family systems theory. Comprehensive Handbook of Social Work and Social Welfare.

doi:10.1002/9780470373705.chsw002018

Doyle, C. A., \& Gaeth, G. J. (1990). Assessing the institutional choice process of studentathletes. Research Quarterly for Exercise and Sport, 61(1), 85-92. doi:10.1080/0270 1367.1990.10607482

Ferrari, M., Verbanac, A., \& Kane, V. (1998). Family systems theory. Psychiatric Comorbidity in Epilepsy: Basic Mechanisms, Diagnosis, and Treatment, 363.

Finley, P., \& Fountain, J. J. (2008). An application of means-end theory to analyze the college selection process of female athletes at an NCAA Division II university. The Sport Journal, 11(2).

Gratton, C., \& Jones, I. (2004). Research methods for sport studies. New York: Routledge.

Heller, D. (2013). In L. Perna (Ed.), The role of finances in postsecondary access and success.

Jones, A.P. (Ed.), The State of College Access and Completion: Improving College Success for Students from Underrepresented Groups. NY: Routledge. (pp. 96-114).

Herzberger, S. (2014). The Division III experience. Retrieved from http://www.ncaa.org/ division-iii-experience.

Johnson, B., \& Christensen, L. (2008). Educational research. Thousand Oaks, CA: Sage.

Jordan, T. L., \& Kobritz, J. I. (2011). University selection factors for Division II softball student-athletes. Journal of Issues in Intercollegiate Athletics, 4, 428-440.

Kankey, K., \& Quarterman, J. (2007). Factors influencing the university choice of NCAA Division I softball players. The SMART Journal, 3(2), 35-49.

Kinzie, J., Palmer, M., Hayek, J. Hossler, D., Jacob, S. A., \& Cummings, H. (2004). Fifty years of college choice: Social, political, and institutional influences on the decisionmaking process. Lumina Foundation for Education.

Kim, D \& Rury, J. (2007). The changing profile of college access: Enrollment patterns in the postwar era. History of Education Quarterly, 47(3), 302-327.

Lapchick, R., Fox, J., Guiao, A., \& Simpson, M. (2015, March 3). The 2014 racial and gender report card: College sport. The Institute for Diversity and Ethics in Sport 
Levine, A., \& Dean, D. R. (2012). Generation on a tightrope: A portrait of today's college front (3rd ed.). San Francisco, CA: John Wiley \& Son.

Maher, M. (2007). You've got messages: Modern technology recruiting through textmessaging and the intrusiveness of Facebook. Texas Review of Entertainment and Sports Law, 8, 125-151.

Misener, K., \& Doherty, A. (2009). A case study of organizational capacity in nonprofit community sport. Journal of Sport Management, 23(4), 457-482.

Morgan, S.J., \& Symon, G. (2004). Essential Guide to Qualitative Methods. Thousands Oaks, CA: Sage.

Morse, J.M., Barrett, M., Mayan, M., Olson, K., \& Spiers, J. (2008). Verification strategies for establishing reliability and validity in qualitative research. International Journal of Qualitative Methods, 1(2), 13-22.

Pauline, J., Pauline, G., \& Allen, C. (2008). Factors influencing college selection by NCAA Division I, II, and III softball student-athletes. Journal for the Study of Sport \& Athletes in Education, 2(3), 366-376.

Pauline, J., Pauline, G., \& Stevens, A. (2004). Influential factors in the college selection process of baseball student-athletes. Journal of Contemporary Athletics, 1(2), 153-166.

Pauline, J. (2010). Factors Influencing College Selection by NCAA Division, I, II and III Lacrosse Players. ICHPER-SD Journal of Research, 5(2), 62-69.

Pauline, J. (2012). Factors influencing college selection by NCAA Division I, II, and III soccer players. International Journal of Sport Management, 13(1), 87-104.

Perna, L., \& Kurban, E. (2013). Improving college access and choice. In L. Perna \& A.P. Jones (Eds.), The State of College Access and Completion: Improving College Success for Students from Underrepresented Groups. NY: Routledge. (pp. 10-33).

Rothbaum, F., Rosen, K., Ujiie, T., \& Uchida, N. (2002). Family systems theory, attachment theory, and culture. Family Process, 41(3), 328-350. PubMed

Ryan, C. J., Groves, D., \& Schneider, R. (2007). A study of factors that influence high school athletes to choose a college or university, and a model for the development of player decisions. College Student Journal, 41(3), 532-539.

Sage, G. H. (1980). Parental influence and socialization into sport for male and female intercollegiate athletes. Journal of Sport and Social Issues, 4(2), 1-13.

Smith, J., Pender, M. \& Howell, J. (2012). The full extent of student-college academic undermatch. Economics of Education Review, 32, 247-261.

Wheeler, S. (2012). The significance of family culture for sports participation. International Review for the Sociology of Sport, 47(2), 235-252.

Wuerth, S., Lee, M. J., \& Alfermann, D. (2004). Parental involvement and athletes' career in youth sport. Psychology of Sport and Exercise, 5(1), 21-33. 